\title{
ZSOLNAI ÁLLAMI FŐREÁLISKOLA, ART NOUVEAU BUILDING AND ITS PAINTED DECORATIONS
}

\author{
Zuzana GRÚŇOVÁ ${ }^{1 *}$, Miloslava BOROŠOVÁ MICHALCOVÁ2 \\ ${ }^{1}$ Department of Building Engineering and Urban Planning, Faculty of Civil Engineering, University of \\ Žilina, Univerzitná 8215/1, 01026 Žilina, Slovakia. \\ ${ }^{2}$ Faculty of Education, Matej Bel University in Banská Bystrica, Ružová 13, 97411 Banská Bystrica, \\ Slovakia. \\ corresponding author: zuzana.grunova@fstav.uniza.sk.
}

\begin{abstract}
The historic art nouveau building of the former high school in Žilina Zsolnai Állami Föreáliskola - is nowadays one of the University of Žilina buildings. Empty, awaiting much needed renovation is school building a subject of the various researches of its art-historical and architectural features. Paper deals with wall painting as a one type decoration among preserved ones in this building. Lack of funds during its initial building and decoration works created rather limited amount motifs and simple technologies. If the whole scope of architectural works of Orth and Somló architectural studio (and the whole set of art nouveau buildings in Žilina) is taken into account, even these simple, but elegant painting in well thought palette of colours could be valuable basis for renovation.
\end{abstract}

\section{Keywords:}

Hungarian folk art motif; Art nouveau;

Secession;

Historical architecture; Art-historical research.

\section{Introduction}

The historic art nouveau building of the former high school in Žilina is architecturally interesting witness of its time. Although not unique in the European art nouveau movement, it is rare example of this Hungarian national variation of style with folk motifs and decorations in Slovakia, namely in the northern Slovak region, so far from the Hungarian borders. Certainly it is a valuable contribution to the genius loci of Žilina historical centre and the contribution to the art nouveau buildings set in the town.

The art nouveau university building is awaiting a much needed renovation and it is empty at the moment. Various kunst-historic, architectonical-historic and restaurational researches are conducted. Their outputs are resourceful addition to sum of data available about architecture of Hungarian team of architects Orth-Somló. Paper deals mainly with the wall painting decorations subject as a part of the whole art nouveau features of the building. This motives are subtle, some of the very simple, due mainly to the financial difficulties at the time. But they can be a basis of decoration repertoire e.g. during planned renovation of this building, but also could be used in a comparative analysis or as an analogies for other art nouveau buildings, influenced by folk Hungarian motives.

\section{History of the building as a school}

Town of Žilina has a relatively long history of various educational institutions. One of the first was high school founded under Jesuit patronage in the monastery at today's Mariánske square. School, still in the monastery building, existed from 1691 till 1776. After Jesuits was school led by Franciscans. As a public school, it was named in 1885 as the king's Catholic Grammar School. In 1900 - 1907 school operated as a Hungarian imperial high school in Žilina - Zsolnai Állami Föreáliskola. [1] 


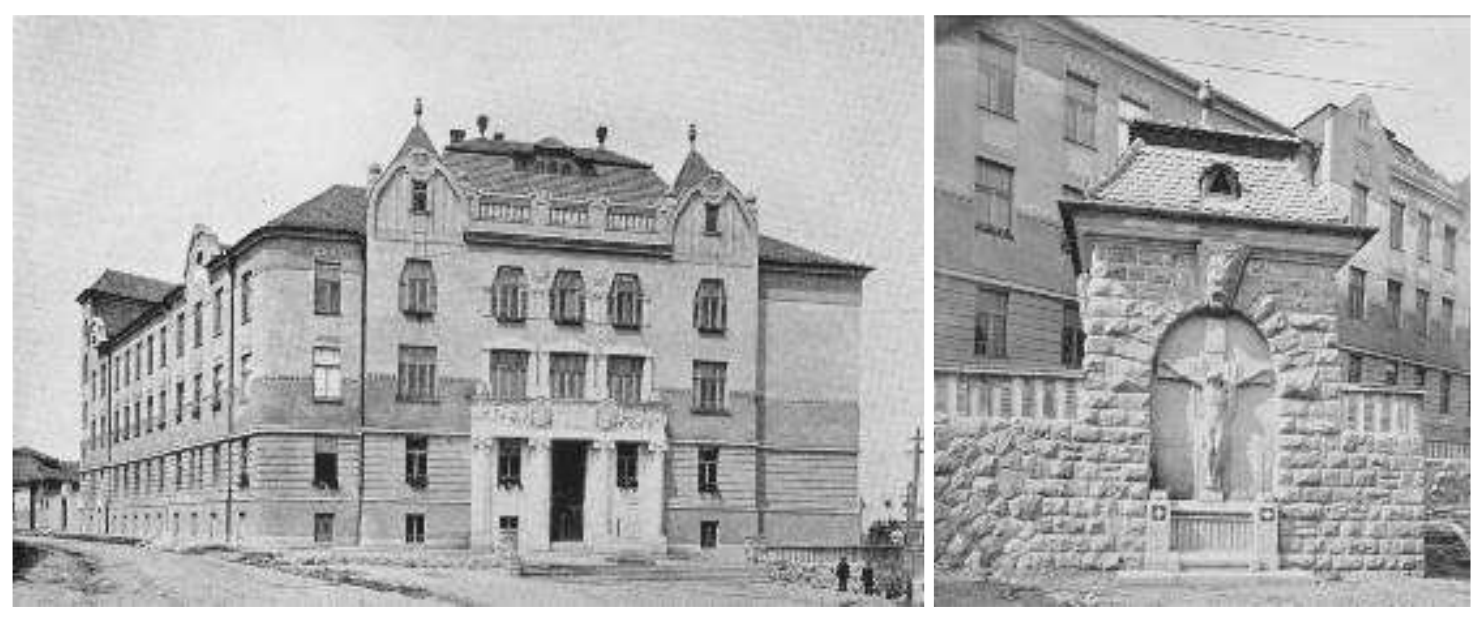

Fig. 1: Žilina high school and a front façade of the chapel in the surrounding wall. Magyar Építőmüvészet 1913. Source [2].

Secondary schools in Austro-Hungarian Empire were perceived as the prestigious building located at significant urban place, and at the same time they should fulfil requirements of modern education. This was also idea behind construction of a brand new building in 1910 - 1913 (design 1909). The role of this school in Žilina was unfortunately also to raise sole use of Hungarian language and culture in the region, that's why higher education was available only in Hungarian, as it was perceived as a proper in Hungarian part of the Austro-Hungarian Empire.

School remained as an educational institution also after the major political change when the new Czechoslovak Republic was established in 1918. Žilina served briefly - for 2 months in 1919 - as a capital of the republic and seat of the government. Some ministry members had their offices in this art nouveau building. Ministry (and capital seat) moved to Bratislava and building was designated to be a school again. Ján Palárik (roman-catholic priest, writer and politician) studied in Žilina, so high school in secession building was given a new title Czechoslovak Public Grammar School of Ján Palárik in his honour and fulfilled its educational role until 1938. The modern history of the building is connected with the history of the University of Žilina. In the years 1960 - 1962 the College of Transport in Prague (VŠD, founded 1953) was moved to Žilina as the College of Transport in Žilina and the new wing marked "building B" was added to the historic former grammar school building "A". VŠD was in 1980 renamed the College of Transport and Communications in Žilina (VŠDS). In November 1996, school gained university status and new name of the University of Žilina. [3]

\section{Hungarian architects Orth and Somló and their designs}

Art Nouveau style was very diverse in Slovakia. The conditions were not ideal, financial background and rural underdevelopment did not allow significant development of liberal, jovial Art Nouveau design in many places with exception of towns with well-established upper level society. Žilina, at the time known by Hungarian name Zsolna, was a busy commercial centre evolving mainly due to the Košice - Bohumín track. Therefore here also quality and attractive Art Nouveau architecture emerged. Architects and builders were local as well as foreign - specifically non-Slovak, but they were the citizens of the large Austro-Hungarian Empire, where Slovakia belongs at that time. The new creative ideas had also brought an industrial exhibition of Upper Hungarian Empire in 1903 in Žilina.

The former high school, building "A" was designed in 1909. Its design is often incorrectly attributed Ignác Alpár, famous Hungarian architect. A lot of information is known about Ignác Álpar, but it is not true about Orth and Somló, unfortunately. It is known (but without proper citations or primary sources), that many young architects started their career in his studio, including his brother-inlaw Ambrus Orth (1871 - 1931). Orth, born in Újarad, graduated from the Budapest University of Technology. [4] Orth, already working as an independent architect, formed studio together with the architect Emil Somló (1877 - 1939) in 1904. They worked together until 1914.

An impressive number of proposals of schools and public buildings appeared in the Orth-Somló portfolio in really short time of a few years. It is not a surprise, considering such a short time, that many of them bear the same or almost the same features. Not all of them are preserved in all buildings up to date. This "self-plagiarism", if it could be considered as such, should not be viewed 
necessarily in negative connotation. Common features and consistent architectural style is really helpful as a basis for renovation, it could provide contemporary architect and interior designer with many useful analogical designs and motives.

Predecessor of all mentioned designs was Állami felsőbb leányiskola és internátus pályatervei in Trencsén, Trenčín, nowadays Slovakia, 1904 - 1905. Girl's school in Trenčín is clearly eclectic, not in art nouveau style, but should be mentioned as a connection between Slovakia architecture and works of Orth-Somló team. [5]

The Orth - Somló designs, which are interesting in terms of analysis of the architectural elements, material-spatial composition and tectonics of the façade of the secession building in Žilina:

- Szatmár (now Romania - Satu Mare): Szatmári törvényszék épületét en Faipari Líceumot (1907). Design by Orth only, but building features monumental Géza Maróti stone portal, almost the same as the high school in Žilina.

- Magyar Királyi Állami Felsőipari Iskola in Szeged, designed in 1909 (built 1912 - 1914) [6].

- Former Népház (The Day nursery for the poor) in Budapest (1909 - 1910) [7].

- The main post office in Sopron (Postapalota), designed in 1909 (built 1911 - 1913) [8].

- Gyergyószentmiklós (now Romania - Gheorgheni): Salamon Ernő gimnázium (1912).

- Győr: Kazinczy Ferenc Gimnázium (1913).

- Polgári Leányiskola, Uzhgorod (built 1912 - 1913 under the guidance of architect Karoj Koch) Originally higher girls' school in Uzhgorod (Hungarian Ungvár, part of the AustroHungarian Empire to 1918, then to 1938 part of Czechoslovakia) now serves as a Linguistic Grammar School of T. G. Shevchenko. [9]

The project for a technical secondary school in Žilina was created by Somló and Orth in 1909. Original documentation of the first variant of design is stored in the Provincial Archives of Hungary in Budapest -- Magyar Országos Levéltár, documentation is also available online [10]. Construction did not go smoothly, with numerous problems and the lack of funds. This led also to reconsidering original scope of the building and drastic cuts in planned much more richer decorations - e. g. see the section drawing of 1909 design with richly decorated foyers and spaces on the second floor. Disposition and general plan was preserved; building was e.g. built a bit shorter and narrower, without planned "stone tower" and numerous sculptures at the main facade. It seems that architects, in the time stress, used at the same time created design for school in Uzhgorod as a "short-cut". Numerous features (main facade, doors and windows style, some ornamentation, balcony shape etc.) are basically the same in Žilina and in Uzhgorod. Uzhgorod's former Polgári Leányiskola has some parts on the facade preserved, but interior apparently lacks any visible painted ornamentation, preserved stone staircase a railing parts are the same as in Žilina (and the same as in Sopron post office and many others from Orth-Somló's portfolio).

\section{Preserved plaster and paint layers}

The basic masonry material for this art nouveau building is brick, measuring $75 \times 150 \times 300 \mathrm{~mm}$. The bottom masonry parts, mainly of the south façade are considerably humid, soaked with salt deposits from the nearby road (winter maintenance). Serious damage to the insulation property and durability of masonry has been proved by measurement also in the whole scope of basement level.

Masonry circa 500 - $1500 \mathrm{~mm}$ above terrain and those parts not affected by water leaks from piping or rain drains remained solid and not damaged. Exterior and interior surface of the masonry is covered primarily by lime-cement plaster in several layers, marked 01 in the Figures (e.g. Fig. 2). Final layer was primarily gypsum-lime mix with fine filler grain; therefore surface was really smooth, without any characteristic plaster texture. The same technology was used to create all of the plasterwork with geometric motifs at the ceilings and columns. At the cracks and the damages all the layers are clearly visible - the first layer of ground, somewhat rougher cement-lime plaster, the second layer of fine grain cement-lime plaster and the third final layer gypsum-lime mix, dense and with smooth surface. All the plasterwork was precise and of the high quality. Only somewhat distorted shapes are visible at the present, covered by many secondary layers of paint (marked in the Figures

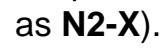



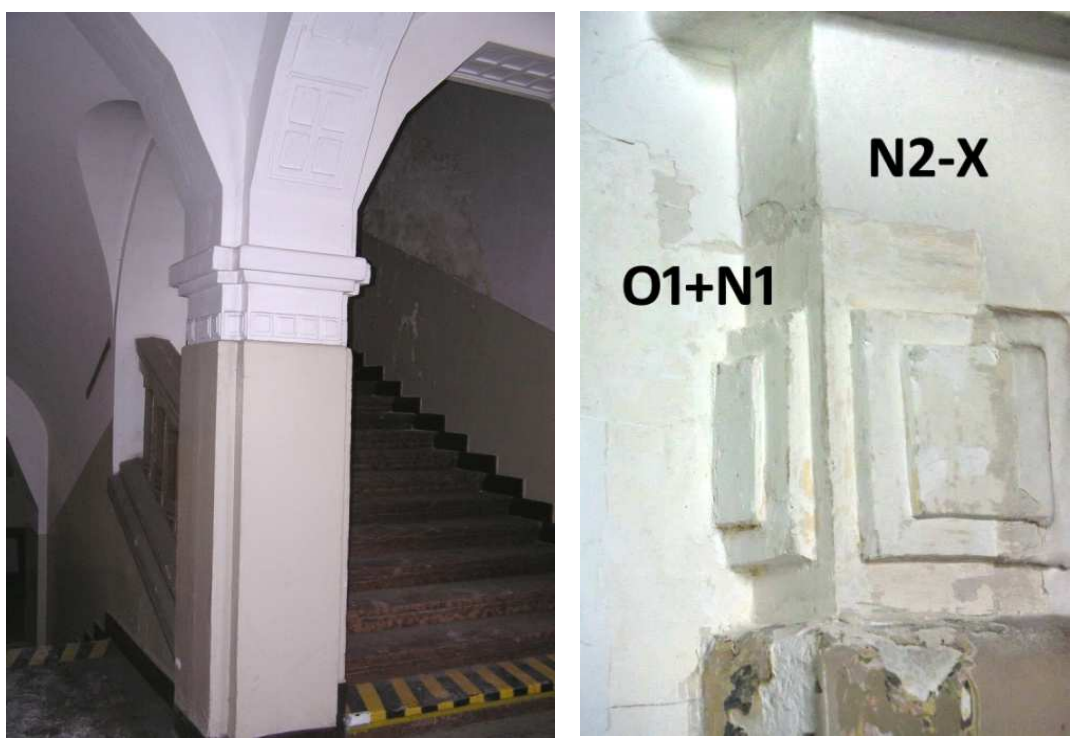

Fig. 2: Gypsum plasterworks at the staircase columns. All the layers are visible:

01 original lime cement plaster layers - base and the second fine one plus smooth fine grained gypsum-lime mix; N1 primary paint coat, lime-casein paint in off-white or very light grey in some cases;

N2-X repeated layers of secondary, modern paints. Some of them are clearly damaging original plaster and/or plasterwork, e.g. oil paint coats at the bottom.

N1 means the original thin final layer of lime-casein paint. Usual colour was off-white or very light grey in some spaces. Originally no distinction between upper part, ceiling and the bottom part was made; all was covered by the same final paint. Visual border was created by the means of elegant simple geometric band motifs, influenced by Hungarian folk art nouveau motifs (the same as in the case of plasterworks).

02, $\mathbf{0 3}$ are the secondary layers of interior plaster. In all detected places it is lime-cement plaster used as a damage repair, at the most cases only locally, at fairly distinctive spots or parts repeatedly damaged by humidity or even water (rain water leaking from damaged or missing downpipe, located in the exterior). Sometime this re-plastering is caused by replacement (windows or doors) or layout changes - mainly in the basement, lately divided into smaller university laboratories, offices and workplaces for print studio. Gypsum plasters are covering electrical wiring or similar repairs and later changes in the plumbing. Original gypsum plasterworks were repaired in modern gypsum mix, roughly following its primary shapes and lines.

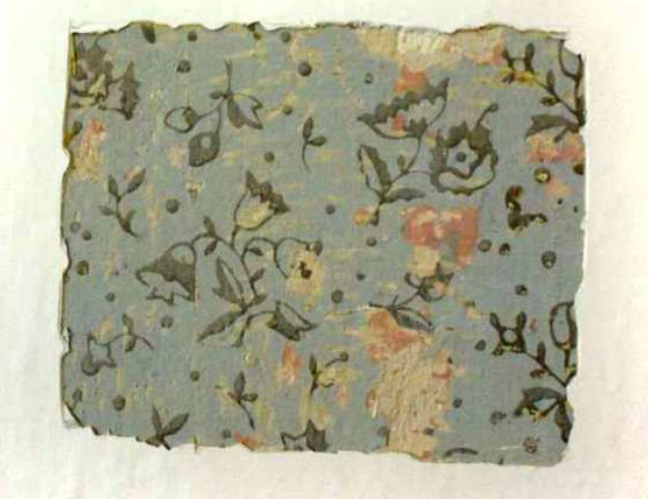

Fig. 3: Example of the modern paint motif (dated circa 1950's), made by patterned paint roller in the Director's apartment at the first floor. Original brown-red hues and ochre layers are visible under the later blue-green-grey paint.

N2 and N2-X are the secondary coats of modern paint, mainly lime and clay paints (Fig. 3). Usually monochromatic white, off-white or very light pastel hues were used for upper parts of the walls 
and ceilings. The lower portions of the wall were painted in darker hues or using various hues of oilbased paints. With the exception of thin black line at the upper border of the oil dados, no decorative motifs were uncovered in the corridors and classrooms. Some modern (mainly floral) patterned paint roller motifs were found in the director's apartment rooms on the first floor.

\subsection{Art nouveau band geometrical motifs, shapes and colours}
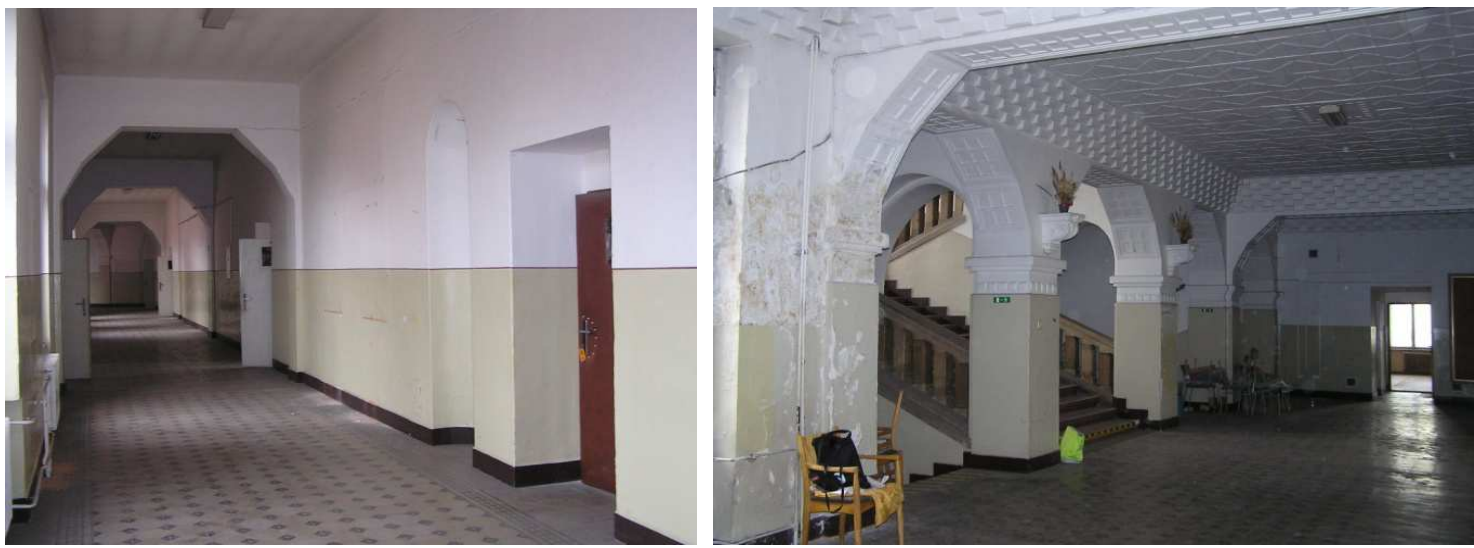

Fig. 4: Present state of corridors and foyer. All final layers are secondary, white paint and beige oil paint. Original ceramic light blue glazed cladding was later painted on, using dark brown oil paint in very thick layers (to be adhesive on ceramic). Reason is unclear, because ceramic tiles and light blue glazing are in a very good condition, maybe to "match overall brownish colour scheme"(?), see Fig. 4.

Floor tiles with grey-beige-anthracite carpet theme are also mostly original, but show considerable wear. Band motifs were painted usually just above present brown line dividing white and beige oil

paint.
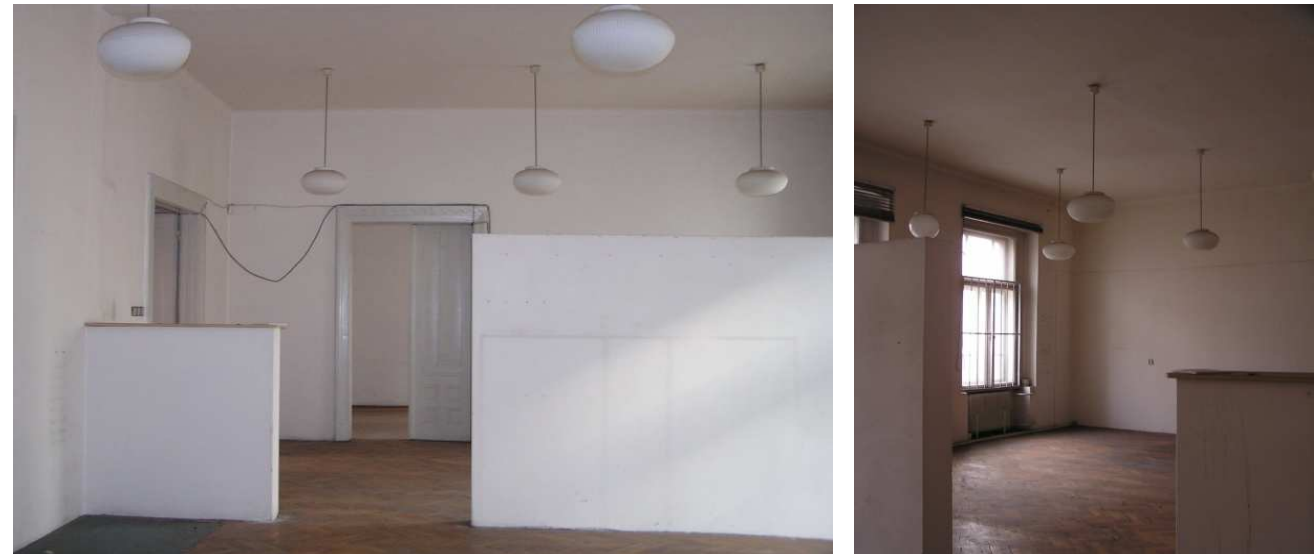

Fig. 5: Present state of the former director's apartment. All final layers are secondary. Note original art nouveau decorated doors (primary glass was replaced by opaque veneer cassettes and painted white). Band motif here encircled the whole rooms at the height of window lintel - motif was so interrupted by window lintel, but ran above doors.

Squares, sometime squares "exploded" diagonally to triangles, arches, waves, rectangles and dots - all together invoking sun, stars even simple landscape like compositions. These are divided according to function of the space. Corridors had simpler motifs (it seems they were the same at all corridors at one time, but various themes gradually appeared). Classrooms were at some cases more decorated; motifs were used not only as a dividing line between bottom part and upper at the height circa $1000-1200 \mathrm{~mm}$ from the floor, but also as a motif joining windows. The second line of band motifs ran at the height of window lintels. This double line makes horizontal division, a kind of a rhythm, helping to visually accommodate considerable height of the walls, mainly in the smaller office or apartment rooms spaces (3200 mm in the basement, $4000 \mathrm{~mm}$ in the all other floors). 

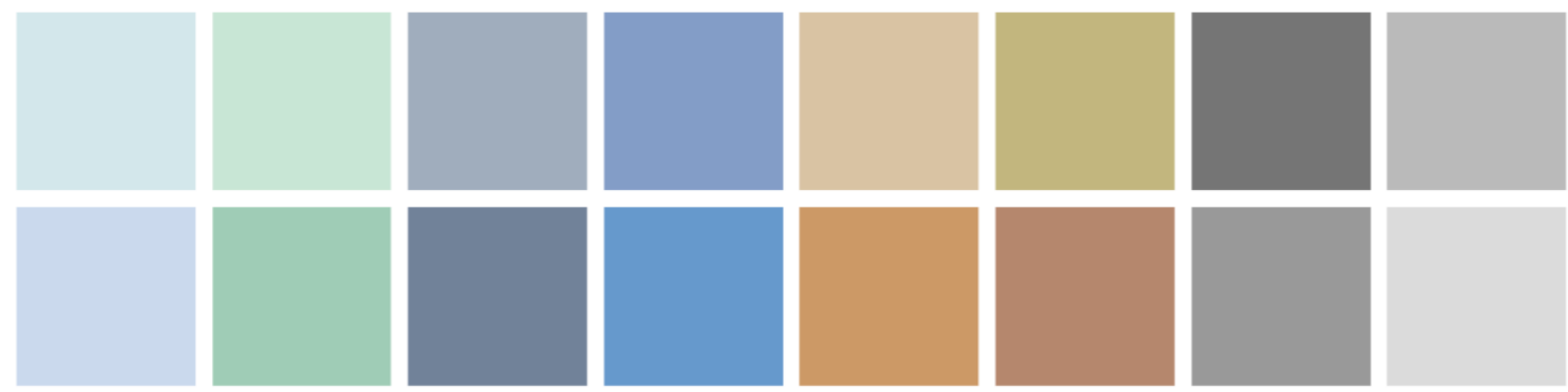

Fig. 6: Approximate range of detected colours. Very light grey-bluish and green-blue-grey tones were represented in much more cases (about $70 \%$ of all colours in the used range). Brown hues are somewhat grey-brown or tinted by yellow - but the soaking by brown pigments from later secondary oil painting have to be taken into consideration.

Blue, green, yellow - all hues muted (Fig. 6), pastel and light were predominantly used in the corridor, offices and classroom motifs. In the back rooms of the building wings were rooms for kitchen and maintenance personnel and storage rooms. More bright colours were used here, but all the motifs are damaged to the great extent, making distinctive pattern detection impossible. Some of samples less elegant and more folk - could be somewhat like blue kitchenware floral motifs with repeating small flowers and leaves or maybe paisleys on white or off-white background.
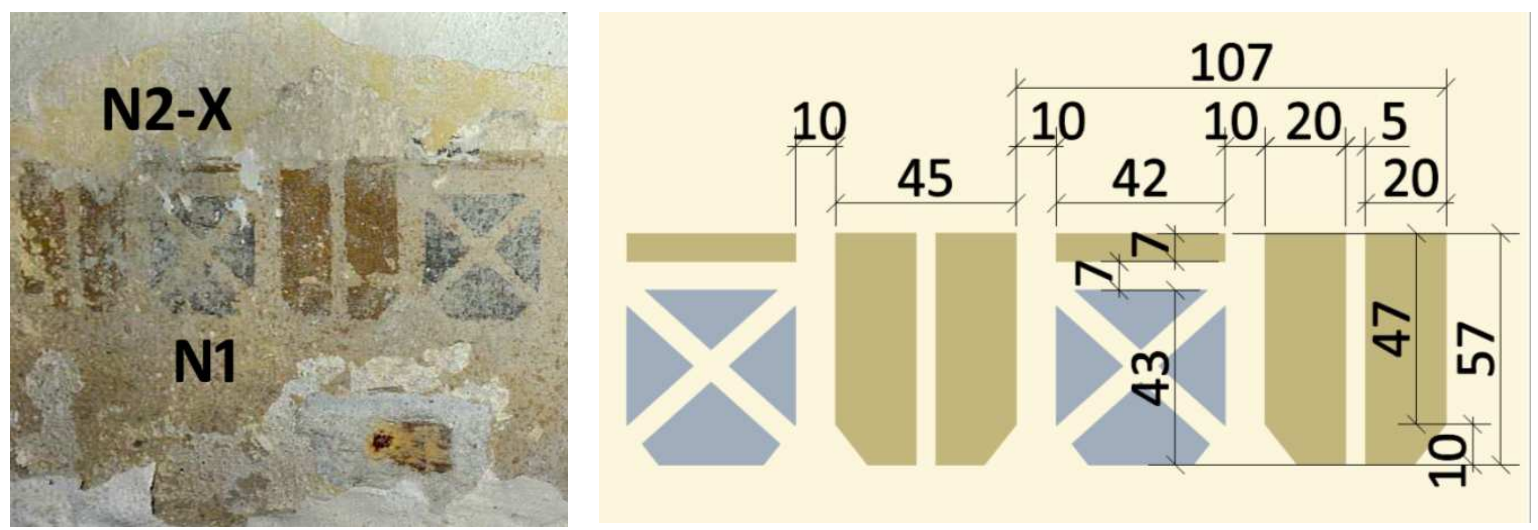

Fig. 7: Square based motif with chamfered corners uncovered at the former student dining hall, later laboratory in the basement. Motif is situated right above secondary added ceramic cladding.

Drawing by authors.
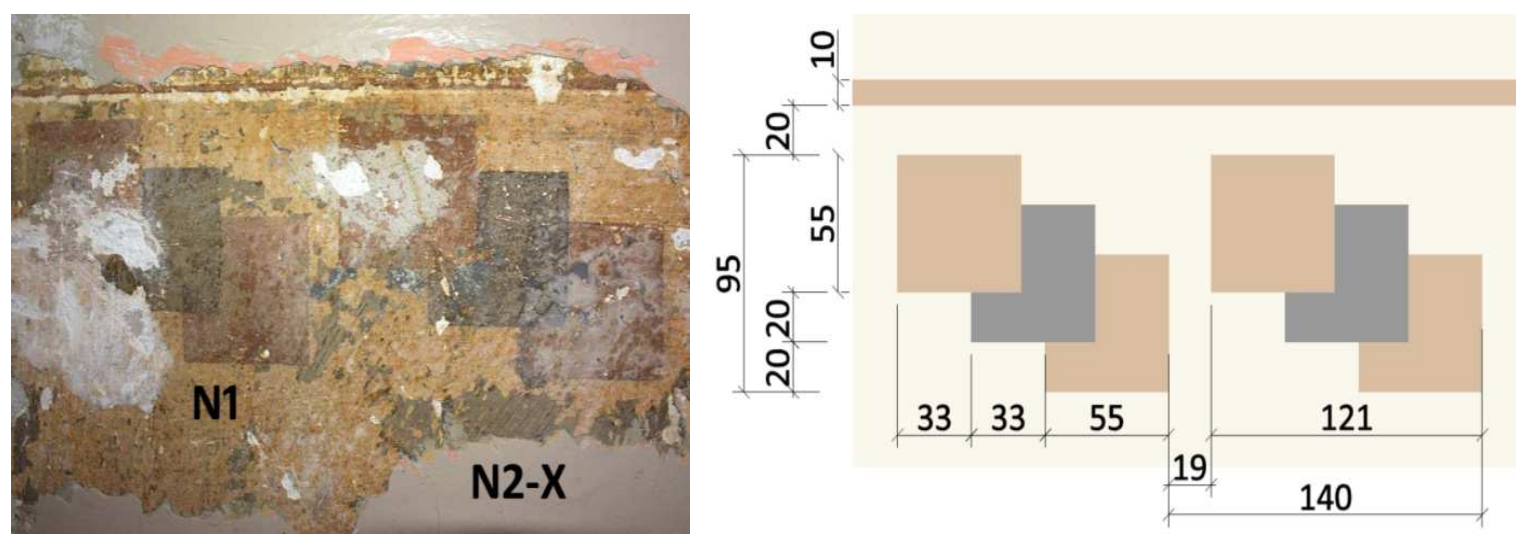

Fig. 8: Simple square based motif uncovered at the staircase pillars in the basement. Colourway is hard to detect thanks to brownish discoloration caused by seeping later oil paint coats. Dimensions are in $\mathrm{mm}$, based on the in-situ measurement by Bc. Yana Yasenenko and Bc. Andrii Artemchuk. 

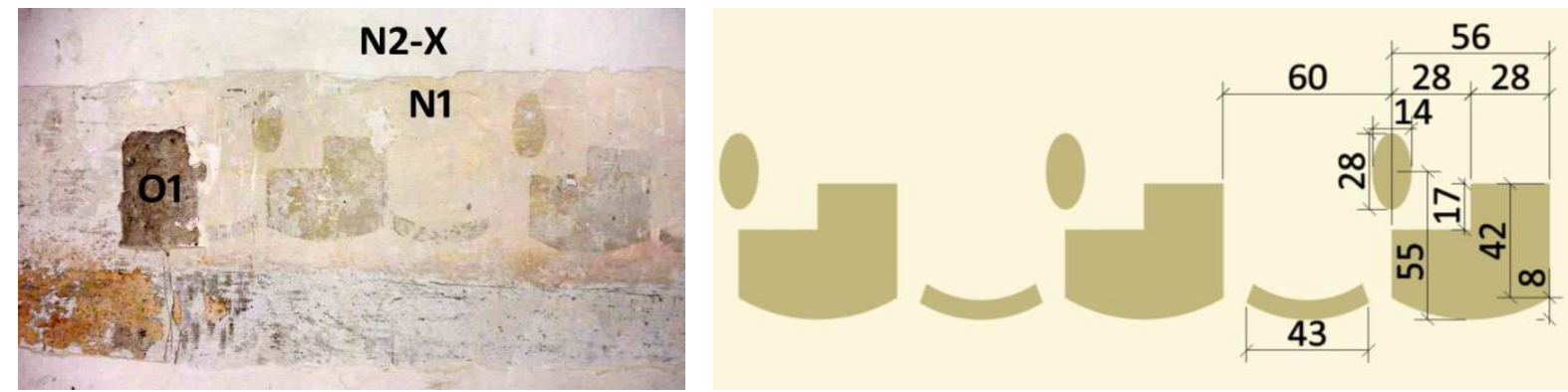

Fig. 9: Art nouveau motif, corridor and hall at the 1st floor, near stone sedile. Dimensions are in mm, based on the in-situ measurement by Bc. Yana Yasenenko and Bc. Andrii Artemchuk.

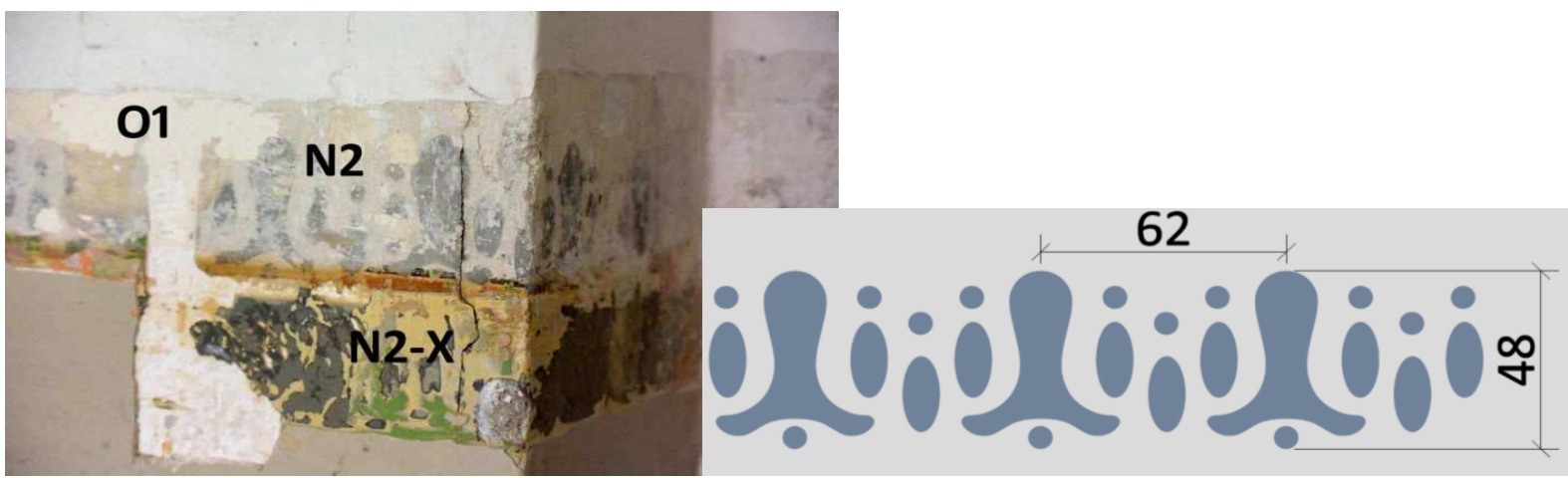

Fig.10: Art nouveau motif, corridor and hall at the 1st to 3rd floor. Dimensions are in $\mathrm{mm}$, based on the in-situ measurement by Bc. Daniela Repaská and Bc. Jozef Smoleň.
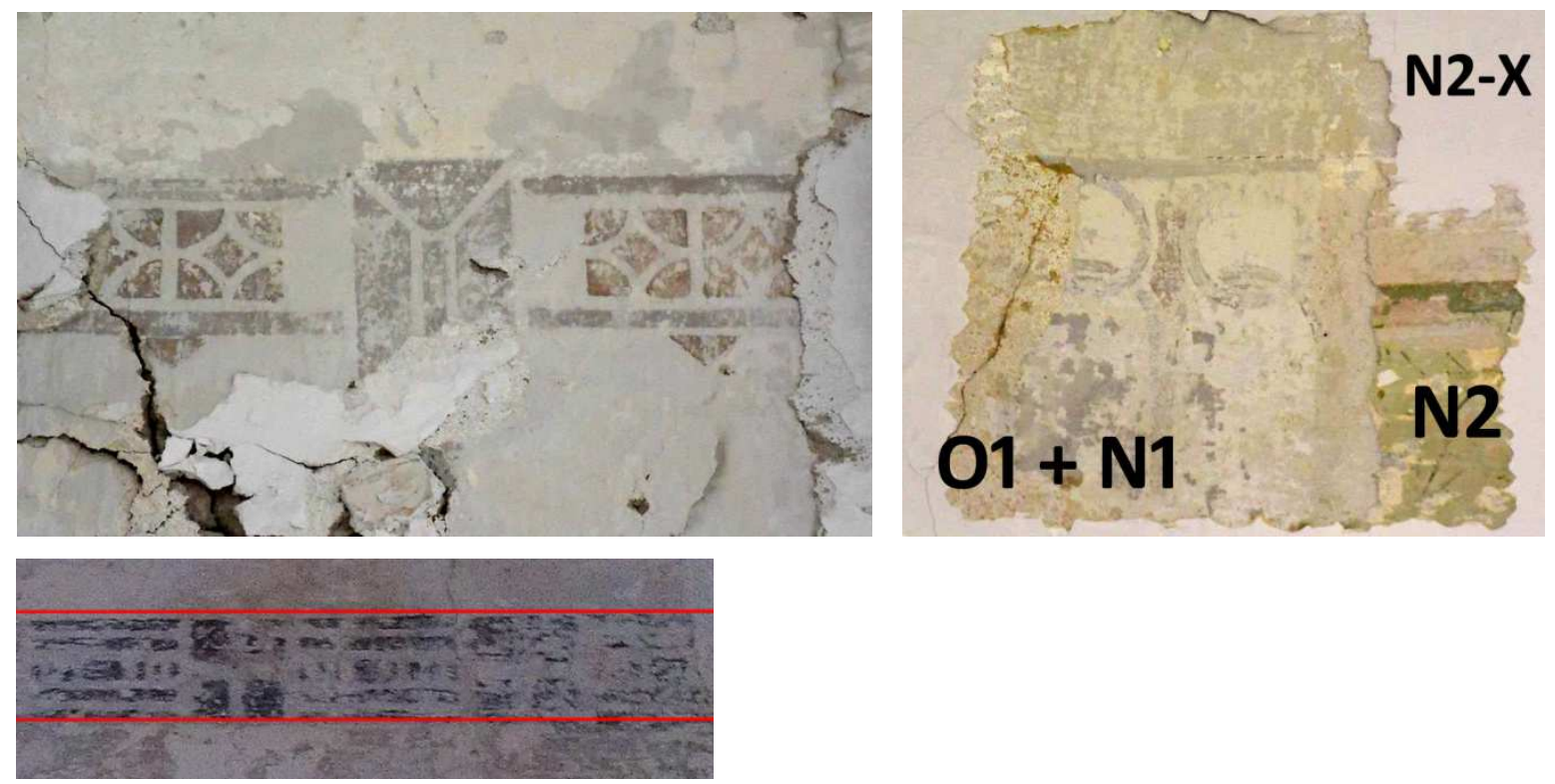


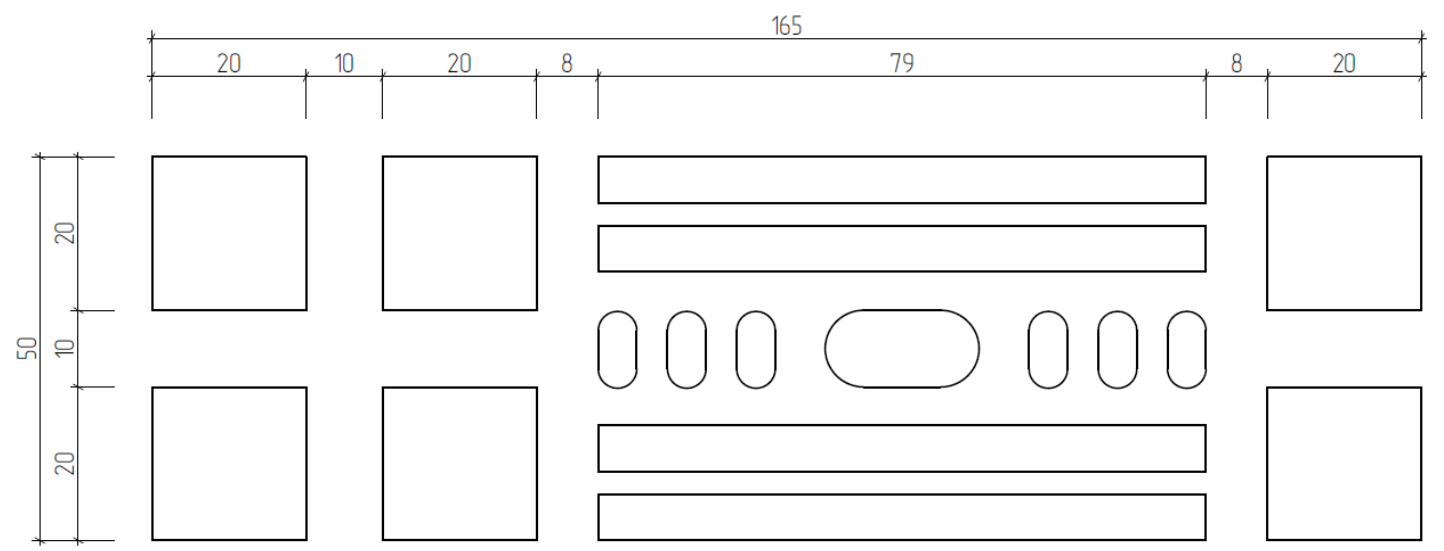

Fig. 11: Art nouveau motifs of the former director's apartment. Bottom drawing by Bc. Yana Yasenenko and Bc. Andrii Artemchuk, others by authors.

Decorative plasters were uncovered during restaurational research too. The first sample is located in the main entrance, staircase space. Originally framed by stucco profillated frame this empty surface looks like prepared (or even used in the past) for same kind commemorative/dedication plaque. Archival research did not mention any such a feature; no photograph of it is preserved. It is possible that if any such a plaque existed, it would be dedicated to Austro-Hungarian Empire or Hungarian school education system and therefore considered as inappropriate in a new Czechoslovak Republic and removed.

Whole surface is covered in three kinds of so called "stucco lustro", a kind of artificial decorative gypsum plaster (Fig. 13), which was designed to remind colour, texture and satin gloss of marble. Maybe it was planned just for this plaque or it is possible, that this kind of decorative plaster was planned for the whole dado part of walls (probably only for foyer and all representative spaces, because it is a work demanding technology, therefore expensive). Lack of fund could cause this plan not to be realized at all and just samples remain, covered by later paint. Also decorative stucco border was removed.
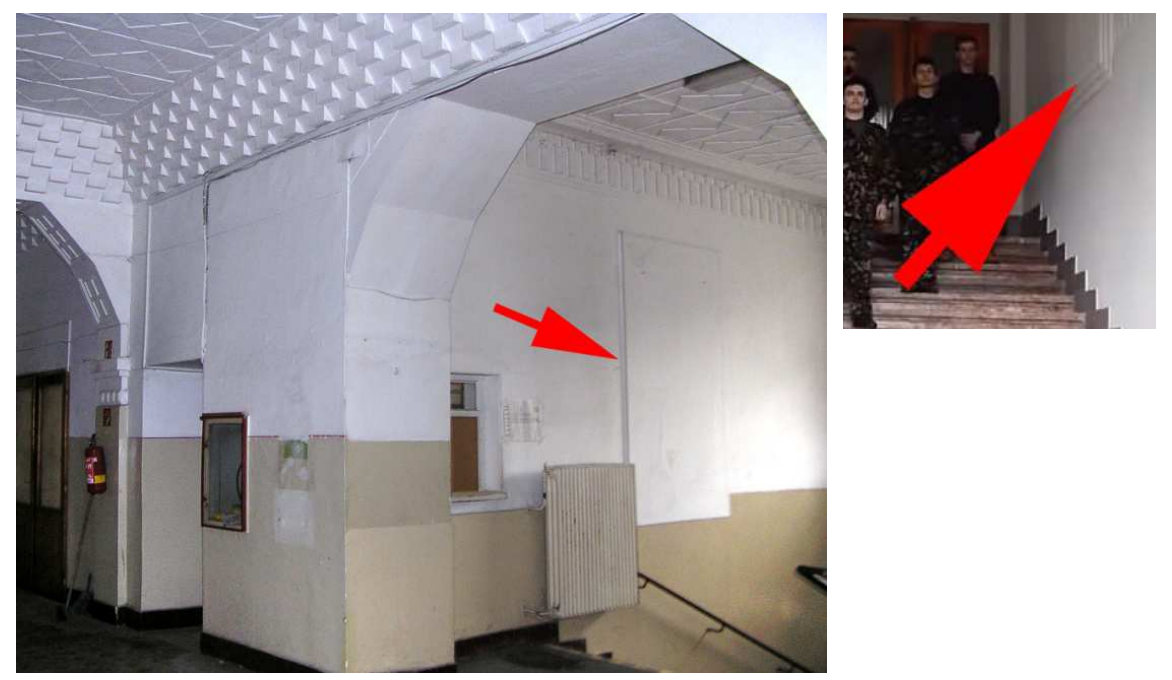

Fig. 12: Left - entrance staircase of art nouveau building in Žilina with location of decorative plaster plaque marked by red arrow. Basically at the same place (maybe even same material) is located "plaque" in school building by Orth - Somló in Uzhgorod, Ukraine. 

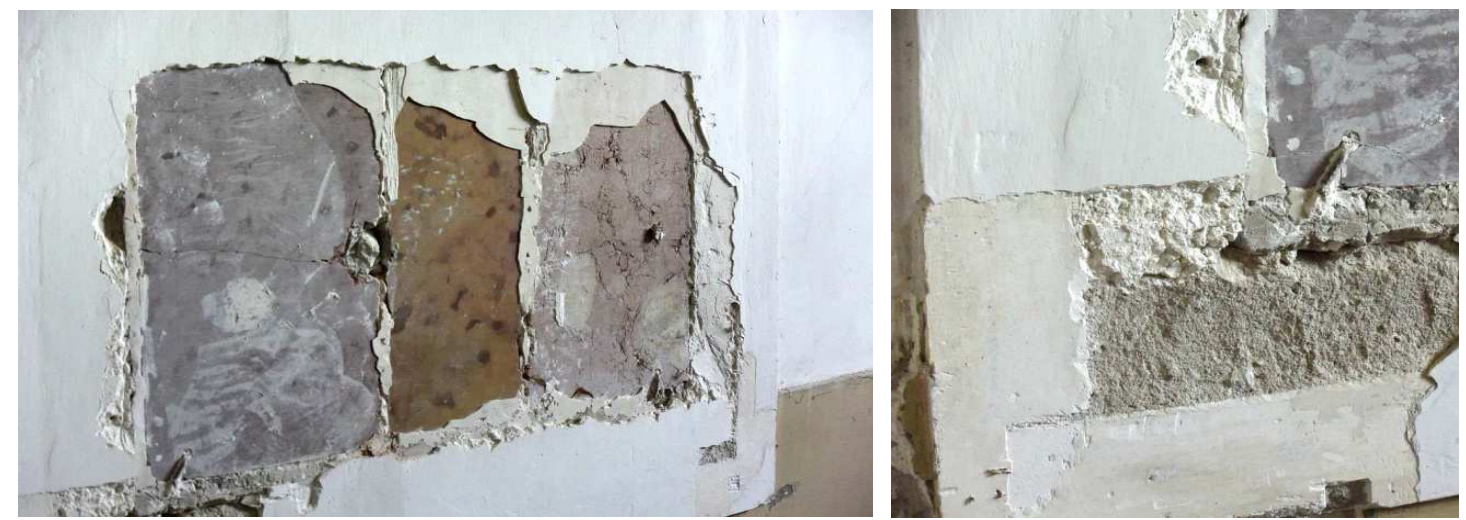

Fig. 13: Žilina school building - samples of decorative "stucco lustro" at the northern wall of entrance staircase. All would correspond with grey-muted blue, green-beige-red-brown colour scheme of all uncovered paintings.
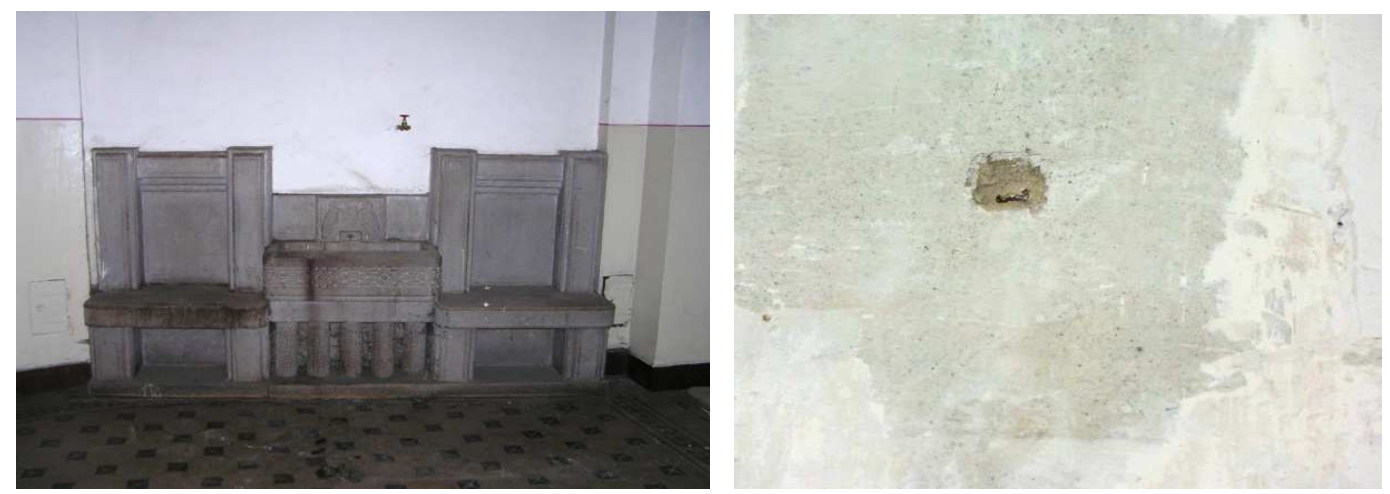

Fig. 14: Stone sedile with fountain in the foyer on the 1st floor and left a fragment of decorative plaster sample.

The second occurrence of decorative plaster is on the wall behind stone decorative sedile with fountain (Fig. 14). This feature is common in art nouveau interior, usually is foyer decorated by sculpture/sculptures or fountain. Art nouveau public buildings in Hungary are often decorated by ceramic cladding and very richly decorated fountains made by famous art nouveau Zsolnay ceramic factory, numerous examples from Budapest are cited in [12]. This plaster consists of rather oily mix of organic resins with small crushed stone particles as filler. Together it should imitate texture and colour of stone sedile. The same technique was used in the exterior at the stone balustrade on the roof. Also this sample near sedile was not used during final phase (lack of funds?) and it is covered by primary plaster.

\section{Conclusions}

Although interior of art nouveau school building is not preserved intact, enough important features remained as samples or fragments under secondary layers of plaster or paint to allow establish colour range, texture and the whole interior scheme of materials and techniques.

The first step in renovation would be careful and considerate removal of all secondary layers distorting profillation and fine details of plasterwork and mechanical cleaning of all parts and surfaces. Cleaning should be performed without any water involved (like in High Pressure Washers WAP). Painting layers, plaster, stucco parts could be damaged and also this technology could not be recommended in the building with a long-term humidity/salinity problems. All non-permeable oil paint coats and already considerably humid and destructed plaster and paint should be removed. Humidity problems are targeted in specialized research and they would be solved for the building and masonry as a whole (out of scope of this paper). Stucco and paintings should be conserved, fixed subsequently by lime injections if necessary, completed missing parts (or adding analogical decoration if 
appropriate). All new added plasters and paint should be lime based, acceptable for renovation of historical buildings.

Final layers, characteristic for original lime-gypsum very smooth, fine grained surfaces could be reach by using mixes of fine lime and inert fillers or appropriate industrial pre-made mixes could be used - kalkglätte, smooth finish plasters. Surface should bear fine traces of metal trowel.

Colour scheme would be consulted with local Board of Monument Preservation in Žilina, but it should stick to the colour scheme of uncovered samples, that mean white, off-white and pastel grey, bluish grey, light beige etc. as a background. Original painted band motifs should be conserved, covered by new layer of lime based plaster to be preserved in the future. Art nouveau motifs could be creatively incorporated to the final interior design for the building that will serve to educational and cultural activities. Also final paintings should incorporate found colour scheme of art nouveau muted pastel hues.

\section{References}

[1] HALAJ, D.: Old schools in Žilina (in Slovak). In: Žilinský Večerník, 04.11 .2008 [online] Žilinský Večerník, archive. [Cited on 10. 1. 2017]. Available at: http://www.zilinskyvecernik.sk.

[2] Digital databasis of the annual magazine Hungarian architects. Magyar Építőművészet 1913. (XI. évfolyam) 8. szám. Available at: http://vpublic.omikk.bme.hu/epmuv/ index.php?page =article\&id= 15154, also available at: https://adtplus.arcanum.hu/hu/view/Magyar PalyazatokEpitomuveszet_ $1913 /$ ?pg $=310 \&$ layout $=$ S

[3] KRÁLIK, C. - BECHNÝ, L'. - ANTOLOVÁ, S.: University of Žilina transformations (1953-2013) (in Slovak). Žilina : Žilinská univerzita, 2013. ISBN: 9788055406411.138 p.

[4] Orth Ambrus. Portrait available at: http://www.postamuzeum.hu/hu/targyak/3432/orth-ambrus1871-1931-epiteszmernok. Short mention in the Magyar Életrajzi Lexikon 1000 - 1990, online available at: http://mek.oszk.hu/00300/00355/html/ABC11371/11511.htm. Short entry about the both architects also at the site of The Art Nouveau Organisation website, online available at: http://www.arvha.org/sitescd/culture2000/SK/cult2000/haut0000000007D30C540.htm

[5] Digital databasis of the architectural magazine [online]. A trencséni áll. felsőbb leányiskola és internátus pályatervei. In: Magyar Pályázatok 1904/05. (II. évfolyam) 10. szám. Available at: http://vpublic.omikk.bme.hu/epmuv/index.php?page=article\&id=14726

[6] SOMORJAI, F.: Csongrád megyei útikönyv, Szeged Tourist Idegenforgalmi Hivatal, 1984. ISBN 9632435397, 9789632435398, p.171.

[7] Archive of the Metropolitan Ervin Szabó Library. V. kerületi Népház [Grafika] : Orth Ambrus és Somló Emil épitészek. Budapest, épült 1909 - 1910 évben [online]. Available at: https://gallery.hungaricana.hu/en/BudapestGyujtemeny/3274/?img=0.

[8] The tender for the construction of the Main Post in Sopron was published in Magyar Építőmüvészet 1910, VIII. évf., 2 sz. (Digital databasis of the annual magazine Hungarian architects 1910, Vol. 8., No 2.). Available at: ttp://vpublic.omikk.bme.hu/ epmuv/index.php? page $=$ article \&id $=15194$

[9] Linguistic Grammar School of T. G. Shevchenko, Uzhgorod (in Russian).High school website and history available at: http://linggymn.at.ua

[10] A Zsolnai Állami Föreáliskola [T 13 No 38/1-12] archive of Hungarian National Archive, Magyar Országos Levéltár, MOL. Available at: https://maps.hungaricana.hu/en/MOLTervtar/878/?list=eyJmaWx0ZXJzljogeyJQSUMiOiBbIIIFUyJ dfSwgInF1ZXJ5ljoglkZFSlo9KFwiVCAxMyBWYWxsXHUwMGUxcy0gXHUwMGU5cyBrXHUwMG Y2em9rdGF0XHUwMGUxc1x1MDBmY2d5aSBtaW5pc3p0XHUwMGU5cml1bWkgdGVydmVrICgx ODMwLTE5MTMpXCIpIn0

[11]BOROŠ, R.: Restaurational research of the secession building of the former Hungarian high school in Žilina, 2016. Mgr. art. Rudolf Boroš, cooperation with Mgr. art. Štefan Siváň, architectural analysis Ing. arch. Zuzana Grúňová, 2016 (in Slovak). Original of the documentation is archived at University of Žilina and also at a regional state office - Board of monument preservation Krajský pamiatkový úrad Žilina, Mariánske námestie.

[12] SÜLE, Ágnes Katalin: On the functions of floral decorations in the houses of Budapest Art Nouveau. In: Art Nouveau \& Ecology. Historical lab 1_Art Nouveau Herbarium, 2010. 